\title{
A quantitative study of histiocytic reticulum cells in diffuse and follicular non-Hodgkin's lymphomas
}

\author{
J CROCKER, RACHEL JENKINS
}

From the Histopathology Department, East Birmingham Hospital, Bordesley Green East, Birmingham B9 $5 S T$

SUMMARY Histiocytic reticulum cells have been counted in 160 lymph nodes, comprising 50 high grade non-Hodgkin's lymphomas, 90 lymphomas of low grade histology, and 20 specimens exhibiting reactive follicular hyperplasia. The histiocytes were shown immunohistochemically by virtue of their content of the cysteine proteinase cathepsin B. A consistent and striking finding was that high grade lymphomas contain many more histiocytes than low grade lymphomas. Immunoblastic neoplasms contain up to $24.2 \%$ of these cells, whereas low grade diffuse lymphomas possess only up to $3.6 \%$ histiocytes. Histiocytic reticulum cells were also counted in benign or malignant follicular lesions in standard areas from follicle centres only. No significant differences were found between low grade lymphomas and hyperplastic nodes. These findings are discussed in relation to previous, more limited studies.

In a previous study ${ }^{1}$ of macrophage (histiocytic reticulum cell) numbers in non-Hodgkin's lymphomas striking differences were found between high and low grade lesions. This investigation, however, was limited to a series of only 20 specimens of non-Hodgkin's lymphomas and $\mathbf{1 0}$ of reactive lymph node hyperplasia. In addition, histiocytic reticulum cells were shown by the $\alpha$-naphthyl acetate esterase reaction, which is also positive in dendritic reticulum cells. The observation that histiocytic reticulum cells were more numerous in high grade than in low grade lymphomas was broadly supported in a subsequent study of acid phosphatase activity in the same small number of specimens. ${ }^{2}$

The current investigation has been designed to enumerate histiocytic reticulum cells in a much larger and wider series of specimens of nonHodgkin's lymphomas. In addition, these cells have been shown by means of an indirect immunoperoxidase reaction for the enzyme cathepsin $B$, which is a useful "marker" of histiocytes in lymphoid tissue. . $^{3-5}$ Unlike lysozyme ${ }^{6}$ (muramidase) and $\alpha_{1}$-antitrypsin, ${ }^{7}$ cathepsin $B$ is not found in polymorphonuclear leucocytes. ${ }^{45}$ Dendritic reticulum cells also lack cathepsin $\mathrm{B}^{5}$ and this technique is therefore also preferred to the $\alpha$-naphthyl acetate esterase reaction as a means of showing histiocytic reticulum cells.

Accepted for publication 24 July 1984

\section{Material and methods}

LYMPH NODES

One hundred and sixty lymph nodes were examined from the same number of patients. These were divided into two main groups - namely, diffuse and follicular specimens. The Kiel Classification ${ }^{8}$ was adopted, although genuine histiocytic lymphomas were also included.

Of a total of 105 diffuse lymphomas, 12 were centroblastic, 21 were immunoblastic, and six were lymphoblastic. Also included were two specimens of genuine histiocytic lymphoma and seven of high grade unclassifiable type. Low grade lesions were also examined: these comprised 19 lymphocytic lymphomas, 17 of centrocytic type, and six of the diffuse centroblastic-centrocytic variety. In addition, 15 lymph nodes replaced by immunocytoma were included (Table 1).

Thirty five follicular lymphomas were studied: these comprised 30 centroblastic-centrocytic specimens, three of centrocytic morphology, and two of the centroblastic variety. Additionally, 20 lymph nodes showing reactive follicular hyperplasia were entered into this group (Table 2).

\section{FIXATION AND STAINING}

The specimens were thinly sliced into $10 \%$ formolsaline and processed to paraffin wax. Sections were cut at $2 \mu \mathrm{m}$ and stained with haematoxylin and 
Table 1 Range of percentages of cathepsin $B$ positive histiocytes in diffuse lymphomas

\begin{tabular}{|c|c|c|c|}
\hline Subtype & Number & $\begin{array}{l}\text { Range of \% } \\
\text { of histiacytes }\end{array}$ & $\begin{array}{l}\text { Mean of \% of } \\
\text { histiocytes }\end{array}$ \\
\hline $\begin{array}{l}\text { High grade } \\
\text { Centroblastic } \\
\text { Immunoblastic } \\
\text { Lymphoblastic } \\
\text { Genuine histiocytic } \\
\text { Unclassifiable }\end{array}$ & $\begin{array}{r}12 \\
21 \\
6 \\
2 \\
7\end{array}$ & $\begin{array}{l}17 \cdot 6-23 \cdot 4 \\
18 \cdot 1-24 \cdot 2 \\
9 \cdot 8-13 \cdot 4 \\
95 \cdot 7-98 \cdot 2 \\
17 \cdot 4-20 \cdot 1\end{array}$ & $\begin{array}{l}19.5(1.7) \\
20.4(1.93) \\
10.9(1.4) \\
96.95(1.77) \\
18.9(0.93)\end{array}$ \\
\hline $\begin{array}{l}\text { Low grade } \\
\text { Lymphocytic } \\
\text { Centrocytic } \\
\text { Centroblastic-centrocytic } \\
\text { Immunocytic }\end{array}$ & $\begin{array}{r}19 \\
17 \\
6 \\
15\end{array}$ & $\begin{array}{l}1 \cdot 4-3 \cdot 4 \\
1 \cdot 2-3 \cdot 1 \\
1 \cdot 7 \quad 3 \cdot 6 \\
1 \cdot 3-2 \cdot 7\end{array}$ & $\begin{array}{l}2.2(0.5) \\
2.02(0.62) \\
2 \cdot 43(0.71) \\
1.9(0.46)\end{array}$ \\
\hline
\end{tabular}

Standard deviations shown in parentheses.

eosin, which enabled classification. ${ }^{8}$

Sections, cut at 3-4 $\mu \mathrm{m}$ thickness, were stained for cathepsin B activity using a standard indirect immunoperoxidase technique. ${ }^{9}$ The use of trypsin before immunostaining was avoided because even brief exposure to this enzyme will abolish staining for cathepsin B.4 The usual controls, including "blocking" of the reaction by the antigen itself, were performed.

The sections were counterstained with Mayer's haemalum, mounted in synthetic medium, and then submitted to the counting procedure.

\section{COUNTING PROCEDURE}

Cathepsin B positive cells (histiocytes) were counted in the two main groups of specimens using a Reichert-Jung (Kontron) "Digiplan" interactive image analyser. ${ }^{10}$ The image of the slide being examined was projected from a microscope on to the graphic tablet and all cathepsin B positive cells were counted and stored on one channel; this was repeated for further random fields until at least 1000 cells had been counted.

In the case of follicular lymphomas and hyperplastic nodes, a different technique was adopted. This entailed counting histiocytes only from the centres

Table 2 Range of percentages of cathepsin $B$ positive histiocytes in follicular lymphomas and hyperplasia (follicle centre areas)

\begin{tabular}{|c|c|c|c|}
\hline Subtype & Number & $\begin{array}{l}\text { Range of \% } \\
\text { of histiocytes }\end{array}$ & $\begin{array}{l}\text { Mean of \% of } \\
\text { histiocytes }\end{array}$ \\
\hline $\begin{array}{l}\text { High grade } \\
\text { Centroblastic }\end{array}$ & 2 & $13 \cdot 8 \& 17 \cdot 2$ & $15.5(1.7)$ \\
\hline $\begin{array}{l}\text { Low grade } \\
\text { Centroblastic-centrocytic } \\
\text { Centrocytic } \\
\text { Reactive hyperplasia }\end{array}$ & $\begin{array}{r}30 \\
3 \\
20\end{array}$ & $\begin{array}{l}1.1-3.7 \\
1.4-2.5 \\
1.1-5.0\end{array}$ & $\begin{array}{l}2.14(0.65) \\
1 \cdot 83(0.48) \\
2 \cdot 22(1.17)\end{array}$ \\
\hline
\end{tabular}

Standard deviations shown in parentheses. of follicles, using a standard square grid centred on each follicle. ${ }^{2}$ "As in the diffuse specimens, at least 1000 cells were counted, necessitating the inclusion of many follicle centres.

At the end of each count the number of cathepsin B positive histiocytes was expressed, by the microprocessor, as a percentage of the total cell count. The mean of each pooled group was calculated for each Kiel subtype, and further statistical analysis was performed using a standard microcomputer.

\section{Results}

In all specimens histiocytic reticulum cells were strongly stained for cathepsin B and were readily counted using the "Digiplan" system.

\section{DIFFUSE LYMPHOMAS}

Striking and consistent results were obtained. In all instances high grade lesions contained significantly greater numbers of histiocytes than specimens of low grade histology. Among the high grade lesions themselves, there were no significant differences in histiocyte numbers from one Kiel class to another, although lymphoblastic lesions tended to contain fewer cathepsin B positive cells than the other lymphomas in this group. Centroblastic specimens contained $17.6-23.4 \%$ histiocytes (mean 19.5\%), immunoblastic lymphomas comprised 18.1-24.2\% histiocytes (mean 20.4\%), and lymphoblastic tumours included $9.8-13.4 \%$ histiocytes (mean $10.9 \%$ ). The unclassifiable high grade lesions contained 17.4-20.1\% histiocytes (mean 18.9\%). The two specimens of true histiocytic lymphoma studied consisted almost entirely of cathepsin B positive histiocytes (95.7 and $98.2 \%$; mean $96.9 \%$ ).

The low grade diffuse lymphomas contained far fewer histiocytes: those of lymphocytic type comprised $1.4-3.4 \%$ (mean $2.2 \%$ ) while those of the centrocytic variety possessed $1 \cdot 2-3 \cdot 1 \%$ histiocytes (mean 2.02\%). The diffuse centroblastic-centrocytic lymphomas contained $1 \cdot 7-3.6 \%$ histiocytes (mean $2.43 \%$ ) and those of immunocytic morphology included 1.3-2.7\% histiocytes (mean 1.9\%). (Fig. 1 and Table 1).

FOLLICULAR LYMPHOMAS AND HYPERPLASIA The numbers of cathepsin $B$ positive histiocytic reticulum cells in standard areas from follicle centres were as follows. In centroblastic-centrocytic lymphomas there were from 1.1 to $3.7 \%$ of these cells (mean $2.14 \%$ ). Centrocytic follicular tumours included $1.4-2.5 \%$ histiocytes (mean $1.83 \%$ ), while the centroblastic follicular lymphomas contained 13.8 and $17.2 \%$ histiocytes (mean $15.5 \%$ ). In the follicle centres of the hyperplastic nodes there were 


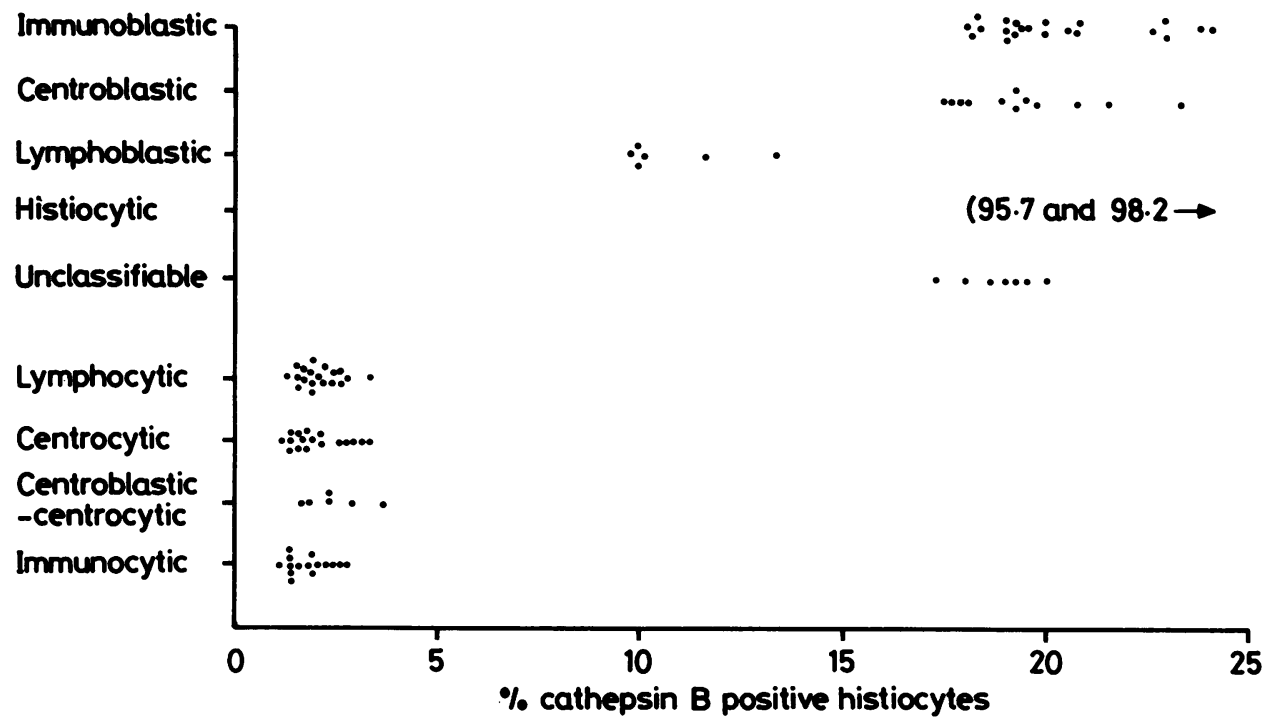

Fig. 1 Scattergram showing distribution of percentages of histiocytes for diffuse lymphomas.

from $1 \cdot 1$ to $5.0 \%$ cathepsin B positive cells (mean $2 \cdot 22 \%$ ). (Fig. 2 and Table 2 ).

Statistical analyses of these data using Student's t test are shown in Tables 3 and 4.

\section{Discussion}

Histiocytic reticulum cells are a ubiquitous component of lymphoid tissues, ${ }^{8}$ and they also occur in Hodgkin's disease and in non-Hodgkin's lymphomas. $^{18}$ Their role appears to include phagocytosis of cellular and nuclear debris, as is frequently evident when they assume the form of "tingible body macrophages." These latter cells are

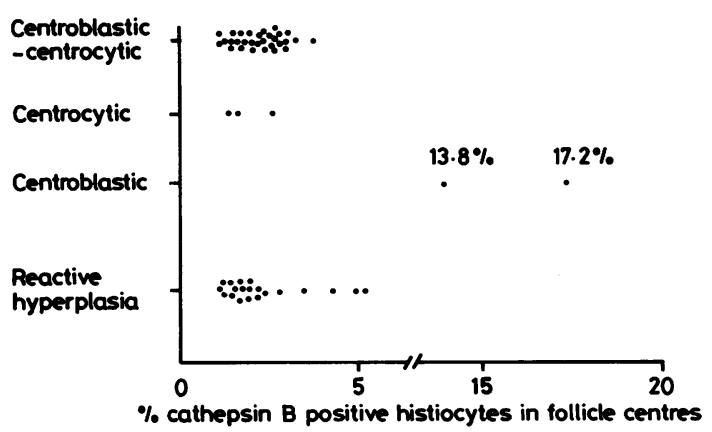

Fig. 2 Scattergram showing distribution of percentages of histiocytes in follicle centres of follicular lymphomas and hyperplastic lymph nodes. prominent in the basal area of reactive follicles ${ }^{12}$ and are intensely positive for various enzymes, including $\alpha$-naphthyl acetate esterase, acid phosphatase, and $\beta$-glucuronidase, ${ }^{13}$ all of which require frozen section techniques for their demonstration. Nevertheless, these enzymes do show many more histiocytes than would be readily seen in conventional paraffin sections stained by haematoxylin and eosin and also reveal that many of these cells are of an arborising shape. ${ }^{1314}$

A previous quantitative study of histiocytes in non-Hodgkin's lymphomas ${ }^{1}$ which made use of frozen sections stained for $\alpha$-naphthyl acetate esterase activity showed that these cells were much more prevalent in high grade than in low grade lymphomas. However, only 20 specimens of nonHodgkin's lymphomas and 10 of follicular hyperplasia were examined. In addition, $\alpha$-naphthyl acetate esterase is not fully satisfactory for such evaluation since it is present in dendritic reticulum cells ${ }^{8}$ and in high endothelial vessels. ${ }^{13}$ is

The present study was undertaken for two main purposes: firstly, to re-examine the numbers of histiocytes in non-Hodgkin's lymphomas using a much larger and wider range of specimens and, secondly, to utilise a more specific means of showing these cells. Cathepsin B, a cysteine proteinase, has been shown repeatedly to be of value as a histiocytic marker in lymphoid tissues ${ }^{3-5}$ and its use is preferable to that of $\alpha$-naphthyl acetate esterase, since dendritic reticulum cells do not contain stainable cathepsin B. ${ }^{5}$ In addition, in contrast to muramid- 
Table 3 Significances of differences between ranges of percentages of histiocytes in diffuse lymphomas

\begin{tabular}{|c|c|c|c|c|c|c|c|c|c|}
\hline Immunoblastic & Centroblastic & Lymphoblastic & Histiocytic & Unclassifiable & Lymphocytic & Centrocytic & $\begin{array}{l}\text { Centroblastic- } \\
\text { centrocytic }\end{array}$ & Immunocytic & \\
\hline - & $0.5>p>0$. & $p<0.001$ & $\mathrm{p}<0.001$ & $0.1>p>0.05$ & $\mathrm{p}<0.001$ & $\mathrm{p}<0.001$ & $p<0.001$ & $\mathrm{p}<0.001$ & Immunoblastic \\
\hline - & - & $p<0.001$ & $\mathrm{p}<0.001$ & $0.5>p>0.1$ & $\mathrm{p}<0.001$ & $\mathrm{p}<0.001$ & $\mathrm{p}<0.001$ & $p<0.001$ & Centroblastic \\
\hline 一 & - & - & $\mathrm{p}<0.001$ & $p<0.001$ & $p<0.001$ & $\mathrm{p}<0.001$ & $p<0.001$ & $\mathrm{p}<0.001$ & Lymphoblastic \\
\hline- & - & - & - & $\mathrm{p}<0.001$ & $\mathrm{p}<0.001$ & $\mathrm{p}<0.001$ & $\mathrm{p}<0.001$ & $\mathrm{p}<0.001$ & Histiocytic \\
\hline - & - & - & - & - & $p<0.001$ & $\mathrm{p}<0.001$ & $\mathrm{p}<0.001$ & $\mathrm{p}<0.001$ & Unclassifiable \\
\hline 一 & - & - & - & - & - & $0.5>p>0.1$ & $0.5>p>0.1$ & $0.5>p>0.1$ & Lymphocytic \\
\hline - & - & - & - & 一 & - & - & $0.5>p>0.1$ & $p>0.5$ & Centrocytic \\
\hline - & - & - & - & - & - & - & 一 & $0.1>p>0.05$ & $\begin{array}{l}\text { Centroblastic- } \\
\text { centrocytic }\end{array}$ \\
\hline - & - & - & - & - & - & - & - & - & Immunocytic \\
\hline
\end{tabular}

Table 4 Significances of differences between ranges of percentages of histiocytes in follicle centres of follicular lymphomas and hyperplasia

\begin{tabular}{lllll}
\hline Centroblastic-centrocytic & Centrocytic & Centroblastic & Hyperplasia & \\
\hline- & $0.5>\mathrm{p}>0.1$ & $\mathrm{p}<0.001$ & $\mathrm{p}>0.5$ & Centroblastic-centrocytic \\
- & - & $0.01>\mathrm{p}>0.001$ & $\mathrm{p}>0.5$ & Centrocytic \\
- & - & - & $\mathrm{p}<0.001$ & Centroblastic \\
\hline
\end{tabular}

ase $^{6}$ and $\alpha_{1}$-antitrypsin, ${ }^{7}$ cathepsin B is not seen in granulocytes. ${ }^{3-5}$ The use of an immunoperoxidase technique for the demonstration of this enzyme also renders possible retrospective studies.

We have confirmed the previous finding that histiocytes are much more numerous in high grade than in low grade non-Hodgkin's lymphomas. Within each group, however, there is little or no significant difference, although true histiocytic lymphomas are clearly composed almost entirely of cathepsin B positive cells. In addition, lymphoblastic lymphomas contain rather fewer histiocytes than other high grade specimens. This is of interest since examination of haematoxylin and eosin stained sections of lymphoblastic lymphomas gives a subjective impression that histiocytic reticulum cells are especially numerous. This is no doubt related to the prominent appearance which results from the "tingible body" structure of these cells in this subtype of nonHodgkin's lymphomas. Certainly, "starry sky" appearances are by no means pathognomonic of lymphoblastic, Burkitt type lymphoma. ${ }^{19}$

The selective examination of follicle centres in follicular specimens has enabled better comparison between benign and malignant lesions than in the previous study ${ }^{1}$ since malignant specimens may, in contrast to the benign specimens, lack mantle zones. ${ }^{1617}$ In addition, medullary and subcapsular sinus lining cells, which contain, for example, $\alpha$-naphthyl acetate esterase, acid phosphatase, ${ }^{18}$ and cathepsin $\mathrm{B},{ }^{5}$ and may be prominent in reactive lymph nodes but absent in follicular lymphomas, are avoided in the counting procedure.
The possible reasons for the differences in numbers of histiocytic reticulum cells in high and low grade non-Hodgkin's lymphomas has previously been discussed.' It is of interest that these cells abound in the basal, centroblast rich area of the reactive follicle,,$^{12-14}$ where there is high cell turnover and, presumably, a relatively increased frequency of apoptosis. Higher in the hyperplastic follicle, where centrocytes predominate, histiocytes are less prevalent, with increasing numbers of dendritic reticulum cells. Thus microenvironmental factors may be important. The large numbers of histiocytes in high grade lymphomas may simply reflect a response to cell death, necrosis, or even immunogenicity.

We are grateful to Mrs Ruth Fry for typing the manuscript, Mrs Pamela Jackson for graphics, and to $\mathrm{Mr} \mathrm{H}$ Sanders for computer programming. The work was supported by a generous grant from West Midlands Regional Research Committee.

\section{References}

${ }^{1}$ Crocker J, Jones EL, Curran RC. A quantitative study of $\alpha$-naphthyl acetate esterase-positive cells in non-Hodgkin's lymphomas and reactive lymph nodes. J Clin Pathol. 1982;35:1066-8.

${ }^{2}$ Crocker J. The enzyme histochemistry of lymphomas. MD Thesis: University of Cambridge; 1983:161-4.

${ }^{3}$ Burnett D, Crocker J, Vaughan ATM. Synthesis of cathepsin B by cells derived from the HL60 promyelocytic leukaemia cell line.J Cell Physiol 1983; 115:249-54.

4 Crocker J. The enzyme histochemistry of lymphomas. MD Thesis; University of Cambridge; 1983:126-37. 
${ }^{s}$ Crocker J, Burnett D, Jones EL. Immunohistochemical demonstration of cathepsin $B$ in the macrophages of benign and malignant lymphoid tissues. J Pathol 1984;142:87-94.

- Mason DY, Taylor CR. The distribution of muramidase (lysozyme) in human tissues. J Clin Pathol 1975;28:124-32.

' Isaacson P, Jones DB, Millward-Sadler GH, Judd MA, Payne S. Alpha-1-antitrypsin in human macrophages. J Clin Pathol 1981;34:982-90.

${ }^{8}$ Lennert K. Malignant lymphomas other than Hodgkin's disease. New York: Springer-Verlag, 1978.

${ }^{9}$ Howie AJ, Burnett D, Crocker J. The distribution of cathepsin B in human tissues. $J$ Pathol 1984 (in press).

${ }^{10}$ Fuggle WJ, Crocker J, Smith PJ. A quantitative study of eosinophil polymorphs in Hodgkin's disease. J Clin Pathol 1984;37:267-71.

"Crocker J, Jones EL, Curran RC. Study of nuclear sizes in the centres of malignant and benign lymphoid follicles. $J$ Clin Pathol 1983;36:1332-4.

12 Curran RC, Jones EL. The lymphoid follicles of the human palatine tonsil. Clin Exp Immunol 1978;31:251-9.

${ }^{13}$ Crocker J. The enzyme histochemistry of lymphoid and nonlymphoid cells of the human palatine tonsil: a basis for the study of lymphomas. $J$ Pathol 1981;134:81-95.

14 Crocker J, Jones EL, Curran RC. The form factor of alpha- naphthyl acetate esterase-positive cells in non-Hodgkin's lymphomas and reactive lymph nodes. J Clin Pathol 1983;36:303-6.

is Freemont AJ, Jones CJP. Light microscopic, histochemical and ultrastructural studies of human lymph node paracortical venules. J Anat 1983; 136:349-62.

${ }^{16}$ Crocker J, Jones EL, Curran RC. A quantitative study of the size of benign and malignant lymphoid follicles. J Clin Pathol 1983;36:1055-61.

${ }^{17}$ Ree HJ, Leone LA. Prognostic significance of parafollicular small lymphocytes in follicular lymphoma. Cancer 1978;41:1500-10.

${ }^{18}$ Crocker J, Williams Mary. An enzyme histochemical study of the sinuses of reactive lymph nodes. $J$ Pathol 1984;142:31-8.

${ }^{19}$ Henry K, Bennett MH, Farrer-Brown G. Classification of the non-Hodgkin's lymphomas. In: Recent Advances in Histopathology No 10. Edinburgh: Churchill Livingstone, 1978:288-9.

Requests for reprints to: Dr J Crocker, Consultant Histopathologist, East Birmingham Hospital, Bordesley Green East, Birmingham B9 5ST, England. 